\title{
A Systematic Literature Review of Art Photography on Social Media in the Age of Digital Culture
}

\author{
Peizhi Qian ${ }^{1, *}$ \\ ${ }^{1}$ Department of Biomedical Engineering, Biomedical Engineering, Tsinghua University, Haidian, Beijing 100084, \\ China. \\ *Corresponding author. Email: qpz18@mails.tsinghua.edu.cn
}

\begin{abstract}
Social media have achieved a prominent role in people's daily life. Several art photographers and institutions have created social media accounts in response to the trend nowadays. The development of art photography on social media should be looked into, and the background of digital culture is also critical in analyzing the topic. The method of literature review is applied with the extensive reading of research articles, literature reviews, and media reports. Main findings are that several art photographers create artworks based upon several issues about social media, such as snapshot, selfie, and identity. Some of these issues are related to popular photography, which reflect the tension between art and popular photography. Art photographers also upload the entire series on social media and interact with the audience. In this way, social media can be seen as a unique medium for art practice, more than simple exhibition of artworks. Art photography on social media also echoes with its history and the age of digital culture.
\end{abstract}

Keywords: Art Photography, Social Media, Digital Culture, Instagram, Popular Photography.

\section{INTRODUCTION}

Social media are interactive technologies where users can create and share information, ideas, interests, and other forms of expression by means of Internet [1]. According to Statista, there are 3.6 billion social media users in 2020 [2]. Some of the most popular social media sites, with over 100 million users as of July 2021, are Facebook, YouTube, Instagram, WeChat, TikTok, and so on [3].

Users are the focus of social media. Use of social media by individuals have been discussed quite deeply in terms of social tool, self-presentation, collective memory, and more. Regarding the platform itself, methodologies like political economy have been applied for analysis [4].

Besides ordinary users, professional ones should also be looked into. What's more, certain organizations have social media accounts as well. A certain field, art, is getting more closely related to social media. Professional users discussed here are artists, and the organizations are art museums and galleries.

Social media and art are more closely related to each other as artists like Banksy went viral on Instagram. A certain art form, photography, hasn't been discussed a lot, as photography is widely accepted by the masses as popular culture. Therefore, photography on social media is mainly analyzed from the perspective of ordinary people. Photographs captured, shared, and used by ordinary people are called domestic photography or popular photography $[5,6]$. Nowadays, people frequently post such photos on social media, among which one specific genre is selfie [7].

Art photography derives from the debate of whether photography is art ever since the invention of photography in the 19th century. The photographer is seen as an artist in art photography, who uses photography as a medium for creative expression. Art photography distinguishes itself from photojournalism, documentary photography, or commercial photography, which depict objective reality rather than subjective ideas or concepts. Photography entered art exhibitions, markets, and museums more frequently in the 20th century, confirming its status as art. For example, MoMA (Museum of Modern Art) established the department of photography and organized several photography exhibitions since the early 20th century [8].

This review aims to sort out the development of art photography on social media. Therefore, several 
artworks and photographers are mentioned. In the context of digital culture, further questions are also included, like the changes in art photography, and the rising of popular photography.

This article is important in that it responds to the growing trends of art photography on new media environment. As digital technology is developing faster than ever, such as new media, social media, and metaverse, its impact on art cannot be neglected. The art form, art photography, and the digital technology, social media, are selected to reflect and discuss this new era, which is beneficial to figuring out relationship between art and technology.

\section{METHOD}

In this review article, the method of literature review is applied. The photographs, data, and analysis were referenced in research journal articles, thesis, books, and websites. Combining all the sources, art photography nowadays can be viewed comprehensively.

\section{ART PHOTOGRAPHY ON SOCIAL MEDIA IN THE AGE OF DIGITAL CULTURE}

\subsection{History of Art Photography}

\subsubsection{Early Ages}

Since the invention of photography in Britain and France in 1839, people praised its picture-taking instead of picture-making [9]. Artists used cameras in place of sketchbooks to record the physical and social world, as photography is usually called a representational system, and is prominent in likeness. In this way, photography released painting from the responsibility to depict the real world, so that artists can experiment with paintings [10].

In the late 19th century, Amateur Photography rose as the technology of film and camera developed rapidly, which allowed the casual amateur to take pictures easily. Serious amateurs wanted to distinct themselves from the masses, trying to claim photography as art [11]. Later on, photographic society like The Linked Ring in Britain and Photo-Secession in America pursued to promote photography as fine art. Alfred Stieglitz, in particular, brought photography to several exhibitions and publications [12].

\subsubsection{Modern and Postmodern Art}

Modern art developed since the late 19th century and the early 20th century. Critics like Clement Greenberg claimed that art should isolate itself from the social context of production [13]. Modern photography was affected by modern art at that time, using light, form, and composition to offer new perceptions. Creativity resides in the artist, instead of the technology [14].

In the 1960s and later on, photography embraced the trend that artists followed society and politics, for example, Vietnam war, civil rights movements, feminism, and student protests in 1968. Art retreated itself from the emphasis on form and medium. The rise of post-modern art and conceptual art challenged the dominance of abstract formalism, shifting to idea and concept [11].

\subsubsection{Analog and digital photography}

In the 1990s, digital cameras went popular, and photography, in some ways, evolved from the analog age to the digital age. Several critics discussed the topic of reproduction, from Walter Benjamin's mechanical reproduction in the early ages of photography to the new age's digital reproduction [15]. Some argue that the materiality of the object and the context where the photographs get their meaning are gone in the digitalization process, while others think aura is transferred to the individualized copy [16, 17]. Nowadays, most cameras used are digital, in place of cameras with photographic films.

\subsection{Art Photography on Social Media}

Social media act as a new medium for art photographers who create artworks of art photography.

In the first place, social media are adopted by art photographers and art institutions such as art galleries and museums to exhibit the photographs. Several photographers and institutions have set up social media accounts, mainly Instagram, and posted the artworks online. Social media, in this sense, work as a museum to exhibit works, or can even be called a "branding tool" [18]. For example, a photographer puts his fashion photographs on social media. Most of the time, artists put their offline works online to expand their impact.

As for the audience, art institutions and photographers can interact with the audience on social media, helping to extend the visitors' aesthetic experience from offline to online environment [19].

Furthermore, social media are treated by some photographers as a unique medium to create works of art, such as Stephen Shore, Cindy Sherman, and Amalia Ulman [20]. In this way, social media are studio or workroom, where photographers can try as they might, rather than simply select and post photographs. Besides, photographers also look into several issues on social media, such as snapshot, selfie, and identity, seeing them as inspirations for artistic creation. In this way, new works of art photography have been created on social media by these pioneer art photographers. 


\subsubsection{Stephen Shore: Snapshot}

Stephen Shore is a renowned photographer from America, having participated in several photography movements in the last century, such as New Topographics. He has long paid attention to banal, ordinary, and unnoticed aspects of life, which can also be called snapshot aesthetic. His iconic series are American Surfaces and Uncommon Places. He has been shooting works with his iPhone and posting them on Instagram since 2014, and successfully brought Instagram photos to exhibitions in MoMA and 303 Gallery. Instagram, in his eyes, is a platform for "visual jotting", or daily practice. What can be seen every day is isolated from its obvious context, and the intricacies beneath are what the photographer is keen on [21].

\subsubsection{Cindy Sherman: Selfie}

Cindy Sherman has long been famous for her photographic self-portraits since the 1970s, in which series she put herself in different contexts. Sherman's works have been thought to convey feminism since she was usually confronted with the male gaze and seemed to be struggling in the frame [22]. Cindy Sherman joined Instagram in 2016, and later in 2017 collaborated with W Magazine on a selfie project, where she uploaded on Instagram a series of seemingly ugly and distorted selfies. In the series, Sherman created grotesqueries to tease photo editing apps, and saw selfies nowadays as the plandid - the planned candid photograph [23]. In this way, Sherman intended to represent ordinary people, utilizing staged, embarrassing, or lovely selfies, but in an exaggerated way [24]. At that time when Trump was repeatedly criticizing women for their appearance, Sherman's works might also be treated as a feminist vow against such voices in a provocative tone [25].

\subsubsection{Amalia Ulman: Identity}

Amalia Ulman, different from Cindy Sherman, is a young artist. She also used selfies extensively in her works and discussed some issues like identity and performance. In 2014, Ulman posted a photography series called Excellences \& Perfections on Instagram, where she pretended as an internet celebrity who wanted to climb to the high class. The series started with a picture of the words "PART 1." in block letters with the word description of "Excellences \& Perfections". Later, she told the life of the girl with photos like selfies, money, and luxuries. The girl was manipulated by her boyfriend and got depressed. The audience interacted with her and offered advice, but then the series ended all of a sudden.

Ulman explored how identity is distorted in social media and questioned authenticity on the Internet as she easily tricked almost everyone. Besides, the project has a feminist orientation, since Ulman expressed the idea that female strivers are shallowly judged by their looks [26].

Both artists, Cindy Sherman and Amalia Ulman, take on the genre of selfie, using their own bodies in the artworks. They explore the topics of self or identity, gendered representations of the body, and the recent trend of social media [27].

\subsection{Art photography, popular photography, and digital culture}

\subsubsection{Digital Culture and Art World}

The word "digital" refers to data stored in a discrete form. Though numerical, linguistic, and other systems are also digital in this sense, "digital" itself is closely related to digital technology like digital binary computer, the Internet, digital film, as well as some cultural responses to them, such as cyberpunk films. Digital culture is culture related to digital technology. Although the culture is a new trend, it can trace back to Alan Turing in the 1930s and several artists like John Cage in the post-war era [28].

Art and digital culture are more connected than ever as new media art like computer graphics, virtual art, and Internet art sprung up with the development of digital technology. New media art worlds became overlapped with the traditional gallery art world, and even changed some aspects of the latter [29].

\subsubsection{Digital Culture and Art Photography}

Digital culture brought about several phenomena on social media. These phenomena have become sources for the artistic creation of art photographers. Trevor Paglen, in 2014, dealt with the topic of surveillance with his project, The Last Pictures [30]. The issue has a heated discussion as social media users are faced with the problem of surveillance more than ever before.

Some phenomena are just in the form of photography, for example, snapshot and selfie which have been discussed above. These genres of photography are not only part of digital culture, but can also be called popular photography. Snapshot photography, a genre from the masses, is a casual way of photography, and even seen as artless. However, several artists turned to snapshot as a formal device in a conceptual approach, and some further used them as raw materials for art practice. MoMA curator John Szarkowski also dealt with snapshot in the 1964 exhibition The Photographer's Eye, claiming its style as "accidental coherence" in the context of postmodernism [31]. Stephen Shore, mentioned above, also experimented with snapshot aesthetics throughout his life, even into the Instagram age. 
From the above analysis, it can be seen that art photography can deal with some issues of popular photography, in an artistic and professional way. Nowadays, popular photography, such as selfie and snapshot, is part of digital culture. In general, digital culture results in popular photography in the present day, and the latter can be dealt with by art photographers.

Hence, in the age of digital culture, art photography and popular photography might have more blurred boundaries. Some argue that, in the networked environment on social media, photographers might be decentered and lose their authorship [32].

\section{CONCLUSION}

Through literature review of art photography, social media, and digital culture, findings are that art photography and social media are closely connected in the age of digital culture. Art photography has developed from analog to digital, and to the nowadays networked social media. The background of digital culture offers several nowadays issues for art photographers.

Art photography on social media is the main point. Social media are mainly used for promotion or exhibition. Art galleries demonstrate their exhibitions, and art photographers post their recent or past works. In this way, art institutions and photographers can gain more popularity, and the audience can extend their aesthetic experience. What is more, some photographers reflect on the medium of social media and see social media as a photography studio. For example, several artists contemplate the phenomenon of popular photography on social media, and try to tackle the issues of gender and self beneath. These artworks mean that social media have influenced the workflow of photographers and provided new topics and perspectives for art creation.

As social media screen and photography are both two-dimensional, photography is easy to demonstrate on social media. Further on, social media, along with digital culture, might be changing art photography in a profound and lasting way. Art photographers and institutions might need to engage more in social media, as the influence might be expanded and the audience can have new aesthetic experiences. Social media also have more issues or problems other than snapshot, selfie, and identity, and they can all become the topics for art photography. Art photographers can reflect on the phenomena, issues, and problems on social media with photography.

All in all, the significance of the article lies in that it gives an outline of art photography on social media to dig into the relationship between art and technology, and discuss the issues we face nowadays. Relationship between art and technology means that art is never pure art. The art of photography and the technology of social media have strong bonds and bring forth some inspiring new works of art. Issues on social media become the topics of artists, such as identity, privacy, and selfie. Discussing these issues from an artistic perspective prompts people to realize the phenomena, reflect on the era, and make possible changes.

In further research, more art photographers and institutions should be considered to demonstrate the whole map of art photography on social media. Other art forms will also be added for analysis. For example, Banksy is seen as a graffiti or street artist, but his works, like many visual arts, are also presented on social media in the form of photography. Therefore, various visual arts will be analyzed to look into the relationship between art and social media to give a big picture, and photography should be seen in a broad sense.

\section{REFERENCES}

[1] Obar, J.A. and Wildman, S. (2015). Social media definition and the governance challenge: An introduction to the special issue. Telecommunications policy, 39(9), 745-750.

[2] Statista. (2020). Number of social network users worldwide from 2017 to 2025 . Retrieved October 18, 2021, from https://www.statista.com/statistics/278414/numberof-worldwide-social-network-users/

[3] Statista. (2021). Most popular social networks worldwide as of July 2021, ranked by number of active users. Retrieved October 18, 2021, from https://www.statista.com/statistics/272014/globalsocial-networks-ranked-by-number-of-users/

[4] Fuchs, C. (2021). Social media: A critical introduction. Sage.

[5] Sarvas, R., \& Frohlich, D. M. (2011). From snapshots to social media-the changing picture of domestic photography. Springer Science \& Business Media.

[6] Coe, B., \& Gates, P. (1977). The Snapshot Photograph: The Rise of Popular Photography, 1888-1939. Ash \& Grant.

[7] Senft, T. M., \& Baym, N. K. (2015). What does the selfie say? Investigating a global phenomenon. International journal of communication, 9(Feature), 1588-1606.

[8] Phillips, C. (1982). The judgment seat of photography. October, 22, 27-63. 
[9] Harker, M. F. (1979). The Linked Ring: the secession movement in photography in Britain, 1892-1910. William Heinemann.

[10] Kosinski, D. (1999). The artist and the camera: Degas to Picasso. Yale University Press.

[11] Wells, L. (2015). Photography: a critical introduction. Routledge.

[12] Keller, U. F. (1984). The myth of art photography: A sociological analysis. History of Photography, $8(4), 249-275$.

[13] Greenberg, C. (2017). Avant-garde and kitsch (pp. 24-27). University of California Press.

[14] Wollen, P. (1978). Photography and aesthetics. Screen, 19(4), 9-28.

[15] Benjamin, W. (2008). The work of art in the age of mechanical reproduction. Penguin UK.

[16] Sassoon, J. (1998). Photographic meaning in the age of digital reproduction. LASIE: Library Automated Systems Information Exchange, 29(4), 5-15.

[17] Davis, D. (1995). The Work of Art in the Age of Digital Reproduction: An Evolving Thesis: 19911995. Leonardo, 28(5), 381-386.

[18] O'Hagan, S. (2018). What next for photography in the age of Instagram. The Guardian.

[19] Suess, A. (2020). Instagram and the art gallery: aesthetic experience, sharing, and space. Griffith University.

[20] Smith, G. (2017). Smoke and Mirrors: Amalia Ulman's Instagram. OAR: The Oxford Arfisfic and Pracfice Based Research Platform, (1).

[21] Reis, C. (2021). @ stephen.shore: an ongoing archive of seeing. photographies, 14(2), 199-220.

[22] Mulvey, L. (1991). A phantasmagoria of the female body: the work of Cindy Sherman (pp. 136-150). na.

[23] Russeth, A. (2017). Facetime with Cindy Sherman: The Artist on Her "Selfie" Project for W, and What's Behind Her Celebrated Instagram. W Magazine.

[24] Sehgal, P. (2018). The Ugly Beauty of Cindy Sherman's Instagram Selfies. The New York Times.

[25] Becker, N. (2018). How Cindy Sherman's Instagram selfies are changing the face of photography. Cit, 09-01.

[26] Langmuir, M. (2016). Amalia Ulman is the first great Instagram artist. Elle Magazine, 16.
[27] Sylvester, S. (2019). The Theatre of the Selfie: Fictive Practices of the Instagram Artist. Body, Space \& Technology, 18(1).

[28] Gere, C. (2009). Digital culture. Reaktion Books.

[29] Gardiner, H., \& Gere, C. (Eds.). (2016). Art practice in a digital culture. Routledge.

[30] Gronlund, M. (2016). Contemporary art and digital culture. Routledge.

[31] Zuromskis, C. (2019). Snapshot Photography: History, Theory, Practice, and Esthetics. A Companion to Photography, 289-306.

[32] Palmer, D. (2019). Decentering the photographer: Authorship and digital photography. In The Routledge Companion to Photography Theory (pp. 385-397). Routledge. 